\title{
Bazı Inceptisol ve Entisol Alt Grup Topraklarının Fizikokimyasal Özellikleriyle Isısal Yayınım Katsayısı Arasındaki Regresyon ílișkilerin Belirlenmesi
}

\author{
İmanverdi EKBERLi
}

Orhan DENGiZ*

Ondokuz Mayıs Üniversitesi, Ziraat Fakültesi, Toprak Bilimi ve Bitki Besleme Bölümü, Samsun

*Sorumlu yazar e-posta (Corresponding author e-mail) : odengiz@omu.edu.tr

Geliș tarihi (Received) : 28.03.2016

Kabul tarihi (Accepted) : 05.09.2016

\section{Öz}

Toprak olușumu süreçlerine, toprak özelliklerinin değișimine, bitki gelișimine vb. önemli düzeyde etki yapan toprak sıcaklığı, profil içerisindeki dağılımı toprağın termal özelliklerine bağıdır. Bu çalıșmada, Inceptisol ve Entisol toprakların bazı fiziksel, kimyasal ve termal özellikleri incelenmiștir. Vertic Haplustept toprakta ortalama günlük sıcaklık $15,1-26,7{ }^{\circ} \mathrm{C}$, Typic Haplustept toprakta ise $13,4-23,9{ }^{\circ} \mathrm{C}$ arasında değișmektedir. Amplitüt değerleri ise maksimum ve ortalama günlük sıcaklığa bağlı olarak alt horizonlara doğru azalmakta ve $1,2-9,2{ }^{\circ} \mathrm{C}-0,6-5,8{ }^{\circ} \mathrm{C}$ aralığında değișmektedir. Typic Ustifluvent, Mollic Ustifluvent1. Mollic Ustifluvent-2 topraklarında günlük ortalama sıcaklık değerleri uygun olarak $16,8-24,8{ }^{\circ} \mathrm{C} ; 16$, 6 $28,8^{\circ} \mathrm{C} ; 16,5-26,7{ }^{\circ} \mathrm{C}$, amplitüt değerleri ise sırasıyla $1,5-7,8^{\circ} \mathrm{C} ; 2,2-8,2^{\circ} \mathrm{C}$ ve $1,5-6,7^{\circ} \mathrm{C}$ aralıklarında belirlenmiștir. Isısal yayınım katsayısı alt horizonlara doğru genellikle artıș göstermektedir. Inceptisol (Vertic

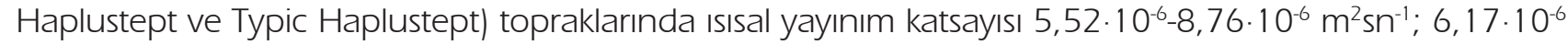
$9,36 \cdot 10^{-6} \mathrm{~m}^{2} \mathrm{sn}^{-1}$ aralığında saptanmıștır. Typic Ustifluvent toprakta ısısal yayınım katsayısı ise düșük olup, $1,71 \cdot 10^{-6}-1,96 \cdot 10^{-6} \mathrm{~m}^{2} \mathrm{sn}^{-1}$ arasında olmaktadır. Mollic Ustifluvent-1 ve Mollic Ustifluvent-2 topraklarında ise

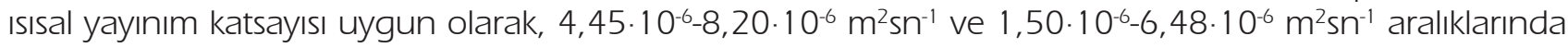
elde edilmiștir. Inceptisol ve Entisol toprakların ısısal yayınım katsayısı ile tarla kapasitesi arasındaki ilișki $p<0,01$ intimal düzeyinde önemli olarak bulunmuștur $(p=0,014 ; R=0,68)$. Organik madde, kil ve kum arasındaki ilișki ise sırasıyla $p<0,05(p=0,031 ; R=-0,62), p<0,01(p=0,005 ; R=0,75), p<0,01(p=0,008$; $R=-$ 0,72 intimal düzeyinde önemli olarak saptanmıștır. Isısal yayınım katsayısı ile tarla kapasitesi, organik madde, kil, kum özellikleri arasında doğrusal $\left(R^{2}=0,79\right)$ ve doğrusal olmayan $\left(R^{2}=0,51-0,81\right)$ regresyon ilișkileri belirlenmiștir.

Anahtar Kelimeler: Amplitüt, ısısal yayınım, inceptisol ve entisol toprak, regresyon ilișkiler, toprak sıcaklığı

\section{Determination of Regression Relationship between Physico-chemical Properties and Thermal Difision Coefficient of some Inceptisol and Entisol Sub Group Soils}

\footnotetext{
Abstract

Diffusion of soil temperature on soil horizons which effects significantly on soil formation processes, plant growing, variation of soil properties etc. depends on soil thermal properties. In this study, some physical, chemical and thermal properties of Inceptisol and Entisol were investigated. Daily mean
} 
temperature value of Vertic Haplustept was determined between $15.1-26.7{ }^{\circ} \mathrm{C}$ while, daily mean temperature changes between $13.4-23.9{ }^{\circ} \mathrm{C}$ for Typic Haplustept. Amplitude values depending on maximum and mean daily temperature decrease along with increasing soil depth and vary between 1.2$9.2^{\circ} \mathrm{C}$ and $0.6-5.8^{\circ} \mathrm{C}$. Daily mean temperature values of Typic Ustifluvent, Mollic Ustifluvent, Mollic Ustifluvent were found $16.8-24.8^{\circ} \mathrm{C} ; 16.6-28.8^{\circ} \mathrm{C} ; 16.5-26.7^{\circ} \mathrm{C}$ and their amplitude values are 1.5-7.8 ${ }^{\circ} \mathrm{C}$; 2.2-8. $2^{\circ} \mathrm{C}$ and $1.5-6.7^{\circ} \mathrm{C}$, respectively. In addition in generally thermal diffusion coefficient value showed increasing with increasing soil depth. In Inceptisol (Vertic Haplustept and Typic Haplustept), thermal diffusion coefficient values were determined between 5.52.10-6-8.76.10-6 $\mathrm{m}^{2} \mathrm{sn}^{-1} ; 6.17 \cdot 10^{-6}-9.36 \cdot 10^{-6}$ $\mathrm{m}^{2} \mathrm{sn}^{-1}$. In Entisol, thermal diffusion coefficient of Typic Ustifluvent was found low value whereas, thermal diffusion coefficient values of Mollic Ustifluvent, Mollic Ustifluvent varies 4.45.1 $0^{-6}-8.20 \cdot 10^{-6} \mathrm{~m}^{2} \mathrm{sn}^{-1}$ and $1.50 \cdot 10^{-6}-6.48 \cdot 10^{-6} \mathrm{~m}^{2} \mathrm{sn}^{-1}$. Relationships between thermal diffusion coefficient and field capacity in Entisol and Inceptisol were significantly found as statistical $p<0.01$ ( $p=0.014 ; R=0.68)$. Moreover, it was determined significantly relationship between organic matter, clay and sand as statistically $p<0.05$ $(p=0.031 ; R=-0.62), p<0.01(p=0.005 ; R=0.75), p<0.01 \quad(p=0.008 ; R=-0.72)$. In addition to that, it was detected between thermal diffusion coefficient and between organic matter, clay and sand linear $\left(R^{2}=0.79\right)$ and nonlinear $\left(R^{2}=0.51-0.81\right)$ regressions

Key Words: Amplitude, thermal diffusion, inceptisol and entisol, regression equation, soil temperature

\section{Giriș}

Toprak sıcaklığı, toprak olușum süreçlerine ve özelliklerine, bitki büyümesine ve gelișimine önemli düzeyde etki yapan faktörlerden biridir. Jenny (1980), iklimin bir öğesi olarak sıcaklığı bağımsız bir toprak yapan faktör olarak belirtmiștir. Sıcaklık, toprak olușumu ile ilgili birçok reaksiyonlara değișik yoğunluk ve hızda etki yapmaktadır. Van't Hoff'un sıcaklık kuralına göre, sıcaklıktaki her $10^{\circ} \mathrm{C}$ lik bir yükselme, kimyasal reaksiyonun hızını iki veya üç misli arttırır. Yeryüzünün değișik yerlerindeki sıcaklık farkları, toprakta meydana gelen kimyasal olayların hızını etkileyerek toprak olușumunu dolaylı biçimde yönlendirir (Tanju, 1996). Sıcaklığın toprak olușumunda yapmıș olduğu en önemli rolünden bir tanesi evapotranspirasyonun ve etkili yağıș miktarının üzerine yapmıș olduğu etkidir. Sıcaklık, bir bölgedeki vejetasyon tipi ve miktarı üzerine ve dolayısıyla olușan humus tipi ve miktarı üzerine etkilidir. Sıcaklık derecesi arttıkça topraktaki organik madde ve dolayısıyla azot miktarı artan mikroorganizma etkinliği yüzünden azalmaktadır. Bunun tipik örneği tropiklerdeki Laterit topraklandır. Yoğun vejetasyona karșın, mineralizasyonunun çok yüksek olușu toprakta organik maddenin tutunmasını engellemektedir. Bu arada açığa çıkan bazik elementlerin etkisi ile olușan $\mathrm{pH}$ yükselmesi, $\mathrm{SiO}_{2}$ yıkanmasına neden olduğundan, Si02/R203 oran 2' den azdır. Daha serin bölgelerdeki Podzol ve Podzolik topraklarda bu durum aksine bir gelișme göstermektedir (Dinç vd., 1987).
Toprak yüzeyinde ve așağı katmanlardaki sıcaklığın günlük ve yıllık değișimi, toprak özellikleri ile birlikte toprakların termal özelliklerine, dolayısıyla ısısal yayınıma önemli düzeyde bağlı olmaktadır (Gao vd., 2007; Onder vd., 2013; Ekberli ve Sarılar, 2015 ). Tikhonravova (2007) tarafindan, tuz miktarı arttıkça, killi tınlı bünyeye sahip topraklarda ısısal yayınımın artıș göstermesi, nemin artması ( $\leq \%$ 40) durumunda ise tuzlu ve tuzsuz toprakların ısısal yayınım katsayıları arasındaki farkın azalması, \% 3540 nem durumunda da yaklașık olarak aynı olması gösterilmiștir. Gri orman topraklarında özgül ağırlık arttıkça, ısısal yayınım katsayısı da artmaktadır. Tarım makinelerinin etkisiyle pulluk katmanının sıkıșması durumunda, \% 26'ya kadar olan toprak neminde ısısal yayınım katsayısı azalmakta, \% 26'dan fazla nem durumunda ise artmaktadır (Arhangel'skaya, 2004). Tikhonravova ve Khitrov (2003), vertisol topraklarda ısısal yayınım katsayısı ile toprağın tanecik fraksiyonları, organik madde, özgül ağırlık ve gözeneklilik değerleri arasında önemli düzeyde ( $R 2=0,81-0,96$ ve $P=0,95$ ) çoklu regresyon ilișkileri elde etmișlerdir. Isısal yayınım, toprak derinliği, nem içeriği, zaman ve sıcaklık değișimine de önemli düzeyde bağlı olmaktadır (Hinkel, 1997). Correia vd., (2012), ısısal yayınımın jeolojik olușum süreçlerinde önemli faktör olduğunu, $26 \mathrm{~m}$ toprak derinliğinde ısısal yayınımın $1,1 \cdot 10^{-6} \mathrm{~m}^{2} \mathrm{sn}^{-1}$ ile $1,6 \cdot 10^{-6} \mathrm{~m}^{2} \mathrm{sn}^{-1}$ (veya $0,011-0,016 \mathrm{~cm}^{2} \mathrm{sn}^{-1}$ ) arasında değiștiğini göstermișlerdir. 
Isı tașınımı denkleminin farkı bașlangıç ve sınır koșullarındaki çözümüne bağlı olarak, ısısal yayınım katsayısının farklı yöntemlerle hesaplanması mümkün olmaktadır (Passerat de Silans vd., 1996). Verhoef vd., (1996), Isı iletkenliği denkleminin çözümünü göz önüne alarak, ısısal yayınım katsayısını belirlemek için beș yöntem (amplitüt, faz, arktanjans, logaritmik, harmonik denklemler) kullanmıșlar, amplitüt ve harmonik denklemlerin daha güvenilir sonuç verdiğini göstermișlerdir. Toprak yüzeyi ısı akıșının tahmin edilmesinde de ısısal yayınım önemli bir faktördür. Isısal yayınım toprak yüzeyi ısı akıșının, dolayısıyla yüzey enerji dengesinin olușumuna, hidrolojik, ekolojik ve atmosferik süreçlerle beraber etki yapmaktadır (Wang ve BouZeid, 2012). Usowicz vd., (1996) tarafından, 4x430 m alanda yapılan araștırmada, toprağın termal özelliklerinin değișimi klasik istatistik ve jeosistatistik yöntemlerle analiz edilmiș, hacim ağırlığı ve su içeriğinin ısısal yayınıma belirgin bir etkisi olduğu gösterilmiștir. Toprakların ısısal yayınım katsayısı ısı iletkenliğiyle doğrusal, hacimsel ısı kapasitesiyle ters orantıııdır. Toprakların ısısal yayınım katsayısı yüksek olduğunda, günlük ve yıllık sıcaklık dalgaları toprak derinliğine daha fazla etki yapmakta ve așağı katmanlarda sıcaklığın gecikmesi azalmaktadır. Ekberli ve Sarılar (2015) tarafından yapılan bir araștırmada, Samsunun Çarșamba ilçesinde, çim örtüsü ile kaplı ve șeftali bahçesinde ağaçların gölgeleme yaptığı farkı iki alanda sıcaklık değerlerine bağlı olarak ısısal yayınım katsayısı belirlenmiștir.

Toprak sıcaklığı değerlerine göre belirlenmesi mümkün olan ısısal yayınım, bitki büyüme mikro klimasını da etkilemektedir (Ghuman ve Lal, 1985). Bazı araștırmalarda ölçülen toprak sıcaklığına bağlı olarak Isı özellikleri parametreleri ve toprak profili boyunca sıcaklığın tahmin edilmesi incelenmiștir (Trombotto ve Borzotta, 2009; Gülser ve Ekberli, 2002; 2004; Ekberli ve Gülser, 2014; Ekberli vd., 2015)

Toprak sıcaklığı aynı zamanda toprakların ölçülebilen ve gözlenebilen özellikleri esas alınarak yapılan morfometrik sınıflandırımasında önemli bir faktör olup, özellikle alt ordo, büyük grup ve familya düzeylerindeki kategorik ayrımlarda kullanılmasında göz önünde bulundurulan önemli bir faktördür. Bu çalıșmanın amacı, Samsun'un Çarșamba ilçesine bağlı Sefalı, Bölmepınar ve Yenikıșla köylerinin yer aldığı ve Yeșilırmak nehrinin getirmiș olduğu aluviyal depositler üzerinde olușmuș Entisol ve Inceptisol toprakların i) bazı fiziksel, kimyasal ve ısısal yayınım özelliklerinin incelenmesi ve ii) ısısal yayınımla bazı toprak özellikleri arasında regresyon ilișkilerin belirlenmesidir.

\section{MATERYAL VE YÖNTEM.}

Çalıșma alanı Çarșamba ilçesine yaklașık 5 km ve Samsun iline ise $44 \mathrm{~km}$ mesafede bulunmaktadır. Entisol ve Inceptisol toprakların toplam alanı 492,9 ha olup, 305500-31 1000 m D ve 4555500-4558500 K (UTM, m) koordinatları arasında, Yeșilırmak Nehri' nin ise sol sahilinde yer almaktadır (Șekil 1).

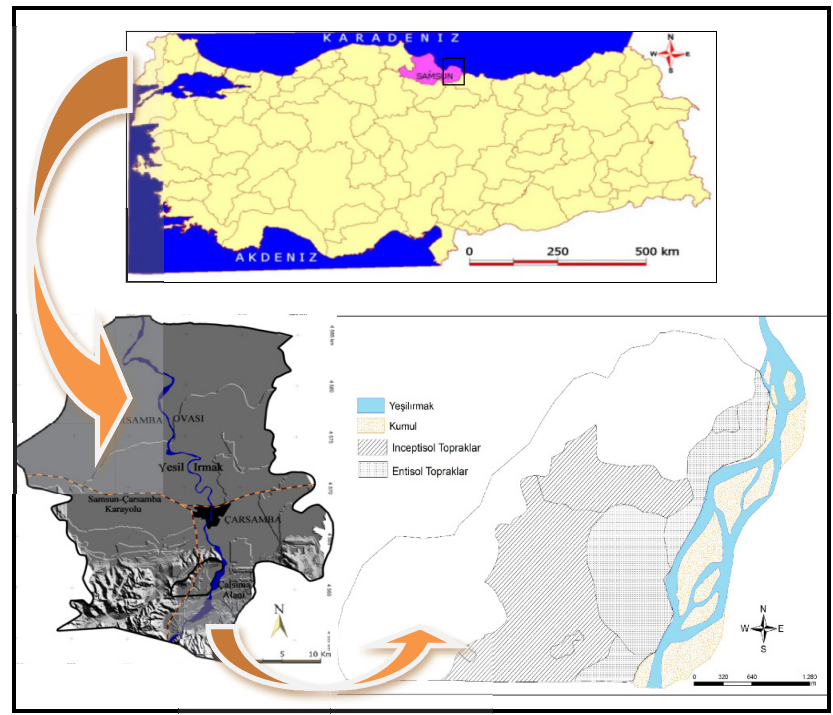

Șekil 1. Çalıșma alanına ait lokasyon haritası

Figure 1. Location map of the study area

Çalıșma alanı üç farklı fizyografik üniteye sahip olup yamaç, etek ve taban (genç ve eski teras) arazilerden olușmakta ve yükselti haritasına göre nispeten taban arazide deniz seviyesinden yükseklik 5-10 m arasında değișim gösterirken, kuzey ve kuzey batı yönlerindeki yükseklik artıșı ile 100 m’ ye çıkmaktadır (Șekil 2).

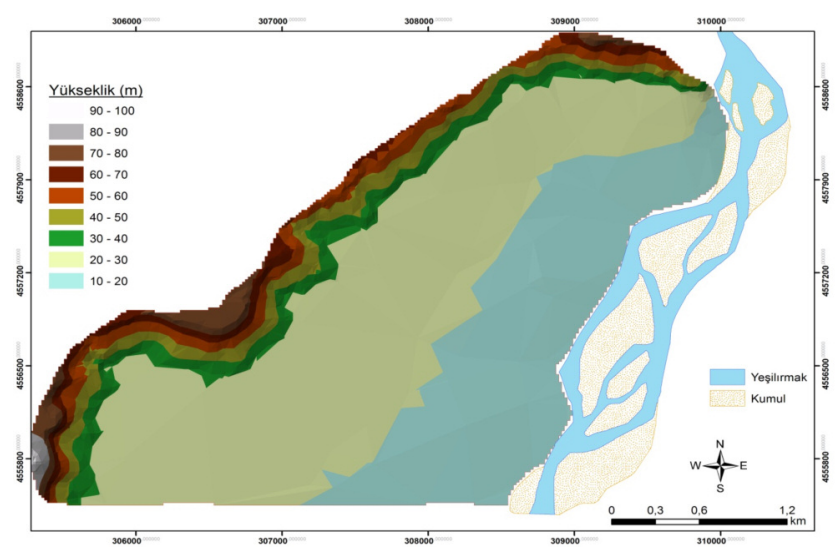

Sekil 2. Çalıșma alanı yükselti haritası

Figure 2. Elevation map of the study area 
Çalıșma alanın büyük bir kısmını olușturan taban araziler \% 0-2 arasında düz düze yakın araziler oluștururken, eğim kuzey batı yönünde artmakta ve kademeli olarak \% 2 ile \% 20 arasında değișim göstermektedir. Yamaç araziler marn ana materyal üzerinde, etek araziler kolüviyal ana materyal üzerinde yer almaktadır. Teras araziler ise Yeșilırmak'ın zamanla tașıdığı aluviyal depozitler üzerinde bulunmaktadır.

Çalıșma alanının yıllık ortalama sıcaklığı $14,3{ }^{\circ} \mathrm{C}$ ve yağıș miktarı ise 1045,2 mm olup yağıșların büyük kısmı kıș ve ilkbahar aylarında düșmektedir. Toprak taksonomisine göre (Soil Survey Staff, 1999) toprak nem kontrol kesitinde $50 \mathrm{~cm}$ derinlikte toprak sıcaklığı $5{ }^{\circ} \mathrm{C}$ 'in üzerinde olduğu dönemin yarısından daha fazlası kadar süre kuru değildir (aridik nem rejiminden farklı). Ayrıca toprak nem kontrol kesiti kıș gün dönümünden sonraki 121 Aralık) 5 ay içerisinde ardıșık olarak 45 gün veya daha fazla nemli olması ve yaz gün dönümünden (21 Haziran) sonraki 4 ay içerisinde ardıșık 45 gün kadar uzun süre kuru kalmaması (Xeric nem rejiminden farklı) nedeniyle toprak nem rejimi ustic olarak belirlenmiștir. Araștırma alanının sıcaklık rejimi; yıllık ortalama toprak sıcaklığı $8{ }^{\circ} C^{\prime}$ den fazla, $15^{\circ} \mathrm{C}^{\prime}$ den az ve $50 \mathrm{~cm}$ 'deki yıllık ortalama kıș ayları toprak sıcaklığı ile yıllık ortalama yaz ayları toprak sıcaklığı arasındaki fark $6{ }^{\circ} \mathrm{C}$ den fazla olduğu için mesic sıcaklık rejimi olarak belirlenmiștir.

Çalıșma alanında yer incelenen 5 adet toprak profilinde, genetik horizon esasına göre morfolojik tanımlamalar yapılmıș ve bozulmuș, bozulmamıș toprak örnekleri alınmıștır. Alınan toprak örnekleri fiziksel ve kimyasal analizler için laboratuara getirilmiștir. Arazide toprakların morfolojik özelliklerinin incelenmesi amacıyla dikkate alınacak kriterler, örneklemeler ve sınıflandırma için Soil Survey Staff (1993; 1999) kullanılmıștır. Alınan örneklerde fiziksel ve kimyasal analizler olarak; Bünye: Hidrometre yöntemi kullanılarak (Bouyoucous, 1951), Tarla kapasitesi: Seramik gözenekler üzerine yerleștirilmiș örneklerin suyla doygun toprak örneği üzerine 1/3 atm basınç uygulamak suretiyle belirlenmiștir (Richards, 1954). Hacim ağırlığı; alınmıș bozulmamıș toprak örneklerinde (Blake ve Hartge, 1986), elektriksel iletkenlik; saturasyon çamurunda kondaktivi metre aleti kullanılarak belirlenmiștir (Soil Survey Staff, 1992). Organik madde; Walkley-Black yönteminin Jackson tarafından modifiye edilmiș șekli ile yapılmıștır (Jackson, 1958). Entisol ve Inceptisol toprakların çalıșma alanı içerisinde dağılım alanları Șekil 1' de gösterilmiștir. Arazide her profile ait horizonlarda cıvalı cam termometre ile (Sterling ve Jaskson, 1986) toprak sıcaklık ölçümleri yapılmıștır.

Ölçülen sıcaklık değerlerinden kullanılarak, toprağın katmanındaki ısısal yayınım katsayısı eșitlik l' e göre hesaplamıștır.

$a=\frac{w\left(x_{i}-x_{i+1}\right)_{2}}{2\left(\ln \left(\mathrm{A}_{i} / \mathrm{A}_{i+1}\right)_{2}\right)}(i=1, n)$

Burada; $\mathrm{A}_{i}$ ve $\mathrm{A}_{i+1}$ uygun olarak toprağın $x_{i}$ ve $x_{i+1}$ derinliklerine ait sıcaklık amplitütü; $w=2 \pi / \mathrm{P}=\frac{6,28}{86400 \mathrm{sn}} \approx 0.0000727 \mathrm{sn}^{-1}$-açısal frekansdir (Trombotto ve Borzotta, 2009; Correia vd., 2012; Arias-Penas vd, 2015). İstatistik hesaplamalar için MiNiTAB-32 paket programından yararlanıımıștır.

\section{BULGULAR VE TARTISMA}

\section{Araștırma Topraklarının Sınıflaması, Bazı Fiziksel ve Kimyasal Özellikleri}

Çalıșma alanı toprakları \% 0,0-0,2 eğime sahip taban arazilerde yayılım gösteren Yeșilırmak'ın biriktirmiș olduğu alüvyon depozitler üzerinde olușmușlardır. Arazide yapılan morfolojik çalıșmaların yanı sıra laboratuar analiz sonuçları dikkate alınarak Toprak Taksonomisine (Soil Survey Staff, 1999) göre dört alt grup içerisinde sınıflandırımıștır. Çalıșma alanı topraklarının toprak taksonomisine göre sınıflandırıması, toprakların pedogenetik özellikleri ile üst tanı horizonları (epipedon) ve bunların altında bulunan yüzey altı tanı horizonları ve özelliklerine göre yapıımıștır. Toprakların olușum süreci sonrası olușan bazı yüzey üstü ve yüzey altı tanı horizonları saptanmıș ve bunlar Entisol ve Inceptisol ordolarına yerleștirilmiștir

Toprak profil numaraları 1, 2 ve 3 no' lu profiller zayıf profil gelișim göstermeleri sonucu Entisol ordosunda sınıflandırımıștır. Profiller akarsuyla tașınmıș fluventik materyal üzerinde yer almaları nedeniyle Fluvent altodosuna, Ustik nem rejimlerinden dolayı Ustifluvent büyük grubuna dahil edilmișlerdir. 1 nolu toprak büyük gruplarının tüm özelliklerini içermeleri nedeniyle Typic Ustifluvent alt grubuna sınıflandırılırken, 2 ve 3 no' lu profiller yüzeyde mollic özellik bulunmasından dolayı (özellikle renk 10 YR 3/3, kuru ve 10 YR 3/2, nemli) Mollic Ustifluvent alt grubuna dahil edilmiștir. 
Profil numaraları 4 ve 5 olan topraklar cambic yüzey altı horizon içermeleri nedeniyle Inceptisol ordosuna, ustic nem rejimleri nedeniyle Ustep alt ordosuna, Haplustept büyük grubuna dahil edilmiștir. 4 nolu profil yüzeyde vertic özellikler göstermesi nedeniyle Vertic Haplustept alt grubuna, 5 nolu profil is büyük grubun tüm özelliklerin tașıması nedeniyle Typic Haplustept dahil edilmiștir.

Inceptisol topraklarının bazı fiziksel ve kimyasal özellikleri Çizelge l'de gösterilmiștir. Inceptisol toprakların EC değerleri düșük olup 0,01 ile 0,06 dS $\mathrm{m}^{-1}$ arasında değișmektedir. Bünye Vertic Haplustept ve Typic Haplustept toprakların genetik horizonlarında killi olup, kil içeriği \% 39 ile 71,8 arasında değișmektedir. Toprakların bünye dağıımı su tutma özelliği ile yakından ilișkili olup, kil içeriği yüksek horizonlarda tarla kapasitesinin değeri yüksek olmaktadır. Tarla kapasitesi Typic Haplustept topraklarda daha yüksek olarak belirlenmiștir.
Entisol topraklarının bazı fiziksel ve kimyasal özellikleri ise Çizelge 2'de verilmiștir. Toprakların EC değerleri 0,03 ile 0,19 dS $\mathrm{m}^{-1}$ arasında değișmektedir.

Organik madde her iki toprakta yüzeyde yüksek miktarda iken $(>\% 3,0)$ bu değer derinlik artıșına bağlı olarak azalma göstermektedir. Toprakların hacim ağırlığı çok değișkenlik gösterip 1,19 ile $1,55 \mathrm{~g} \mathrm{~cm}^{-3}$ arasında değișmektedir.

Toprakların bünye dağıımları, Typic Ustifluvent olarak tanımlanan profil 4 ile Mollic Ustifluvent olarak tanımlanan profil 8' de tınlı bünyeye sahiptir. Mollic Ustifluvent sınıflandırılan 5 no' lu profilin yüzey toprağı kumlu tın, yüzey altı horizon ise siltli killidir. Toprakların kum içeriklerinin yüksek olușu hacim ağırlıklarının yüksek, buna karșın su tutma kapasitelerinin düșük olmasına neden olmaktadır.

Çizelge 1 . Inceptisol toprakların bazı fiziksel ve kimyasal özellikleri

Table 1. Some physical and chemical properties of the Inceptisol

\begin{tabular}{|c|c|c|c|c|c|c|c|c|c|}
\hline \multirow[t]{2}{*}{ Horizon } & \multirow{2}{*}{$\begin{array}{c}\text { Derinlik } \\
\mathrm{cm}\end{array}$} & \multirow{2}{*}{$\begin{array}{c}\text { EC } \\
\mathrm{dS} \mathrm{m}^{-1}\end{array}$} & \multirow[t]{2}{*}{ OM \% } & \multicolumn{4}{|c|}{ Bünye } & \multirow{2}{*}{$\begin{array}{c}\mathrm{H} . \mathrm{A} \\
\mathrm{g} \mathrm{\textrm {cm } ^ { - 3 }}\end{array}$} & \multirow{2}{*}{$\begin{array}{l}W \\
\%\end{array}$} \\
\hline & & & & $\begin{array}{l}\text { Kil } \\
\%\end{array}$ & $\begin{array}{c}\text { Silt } \\
\%\end{array}$ & $\begin{array}{c}\text { Kum } \\
\%\end{array}$ & Sinıf & & \\
\hline \multicolumn{10}{|c|}{ Vertic Haplustept } \\
\hline Ap & $0-23$ & 0,06 & 3,93 & 69,3 & 19,5 & 11.2 & C & 1,22 & 36,2 \\
\hline Bw1 & $23-58$ & 0,08 & 2,49 & 64,5 & 28,0 & 7.5 & C & 1,19 & 37,7 \\
\hline Bw2 & $58-90$ & 0,04 & 1,65 & 39,0 & 36,2 & 24.8 & C & 1,39 & 27,0 \\
\hline $\mathrm{Cl}$ & $90+$ & 0,11 & 1,01 & 21,8 & 31,3 & 46.9 & SL & 1,55 & 16,7 \\
\hline \multicolumn{10}{|c|}{ Typic Haplustept } \\
\hline Ap & $0-30$ & 0,01 & 3,15 & 40,9 & 29,6 & 29.5 & C & 1,35 & 28,2 \\
\hline Bw1 1 & $30-64$ & 0,01 & 3,08 & 67,1 & 22,5 & 10.4 & C & 1,22 & 36,7 \\
\hline Bw2 & 64-107 & 0,07 & 1,38 & 71,8 & 19,6 & 8.6 & C & 1,20 & 38,3 \\
\hline C & $107+$ & 0,03 & 0,35 & 64,8 & 23,9 & 11.2 & C & 1,21 & 38,7 \\
\hline
\end{tabular}

EC: Elektiriksel iletkenlik OM: Organik madde, HA: Hacim ağırlığı, W: Tarla kapasitesi

Çizelge 2. Entisol toprakların bazı fiziksel ve kimyasal özellikleri

Table 2. Some physical and chemical properties of the Entisol

\begin{tabular}{|c|c|c|c|c|c|c|c|c|c|}
\hline \multirow[t]{2}{*}{ Horizon } & \multirow{2}{*}{$\begin{array}{c}\text { Derinlik } \\
\mathrm{cm}\end{array}$} & \multirow{2}{*}{$\begin{array}{c}\mathrm{EC} \\
\mathrm{dS} \mathrm{m}^{-1}\end{array}$} & \multirow[t]{2}{*}{ OM \% } & \multicolumn{4}{|c|}{ Bünye } & \multirow{2}{*}{$\begin{array}{c}\mathrm{HA} \\
\mathrm{g} \mathrm{cm}^{-3}\end{array}$} & \multirow{2}{*}{$\begin{array}{l}W \\
\%\end{array}$} \\
\hline & & & & $\begin{array}{l}\text { Kil } \\
\%\end{array}$ & $\begin{array}{l}\text { Silt } \\
\%\end{array}$ & Kum \% & Sinıf & & \\
\hline \multicolumn{10}{|c|}{ Typic Ustifluvent } \\
\hline Ap & $0-18$ & 0,08 & 3,96 & 21,6 & 45,5 & 32,8 & $\mathrm{~L}$ & 1,31 & 23,8 \\
\hline A2 & $18-37$ & 0,11 & 2,47 & 17,7 & 37,4 & 44,9 & $\mathrm{~L}$ & 1,44 & 18,1 \\
\hline C & $37+$ & 0,13 & 1,01 & 7,1 & 10,6 & 82,3 & LS & 1,52 & 6,9 \\
\hline \multicolumn{10}{|c|}{ Mollic Ustifluvent-1 } \\
\hline Ap & $0-21$ & 0,11 & 4,17 & 19,8 & 21,1 & 59,1 & SL & 1,38 & 19,1 \\
\hline$A 2$ & $21-55$ & 0,06 & 2,85 & 43,9 & 42,6 & 13,5 & $\mathrm{SiC}$ & 1,27 & 31,8 \\
\hline C & $55+$ & - & - & - & - & - & - & - & - \\
\hline \multicolumn{10}{|c|}{ Mollic Ustifluvent-2 } \\
\hline$A$ & $0-15$ & 0,03 & 5,20 & Kil & Silt & Kum & $\mathrm{L}$ & 1,25 & 26,9 \\
\hline $\mathrm{C} 1$ & $15-47$ & 0,19 & 1,47 & 26,0 & 37,7 & 36,3 & $\mathrm{~L}$ & 1,49 & 19,1 \\
\hline$C 2$ & $47+$ & - & - & 21,8 & 43,4 & 34,8 & - & - & - \\
\hline
\end{tabular}

EC: Elektiriksel iletkenlik OM: Organik madde, HA: Hacim ağırlığı, W: Tarla kapasitesi 


\section{Araștırma Alanı Topraklarının Bazı Termal Özellikleri}

Çalıșma alanında yer alan toprak horizonlarında ölçülen sıcaklık değerlerine bağı olarak, horizonlardaki amplitüt ve ısısal yayınım katsayıları, sırasıyla $A=T_{m}-T_{\text {ort }}$. (Tm=horizondaki maksimum; $\mathrm{T}_{\text {ort }}=$ ortalama sıcaklıktır) ve eșitlik 1 kullanılarak hesaplanmıștır.

Inceptisol topraklarının bazı termal özellikleri Çizelge 3'de gösterilmiștir. Çizelge 3'den görüldüğü gibi, inceptisol topraklarda en düșük maksimum ve minimum sıcaklık sırasıyla $14,4^{\circ} \mathrm{C}$ ve $10,7^{\circ} \mathrm{C}$ olup, Typic Haplustept toprağın Bw2 (64-107 cm) horizonunda; en yüksek maksimum ve minimum sıcaklık değerleri ise (uygun olarak $35,9^{\circ} \mathrm{C}$ ve $20,5^{\circ} \mathrm{C}$ ) Vertic Haplustept toprağın yüzeyinde saptanmıștır. Ortalama günlük sıcaklık durumu ise, Vertic Haplustept toprağın yüzeyinde en yüksek $\left(26,7^{\circ} \mathrm{C}\right)$; Typic Haplustept toprağın C $(107+\mathrm{cm})$ ana materyalinde en düșük $\left(13,4^{\circ} \mathrm{C}\right)$ olarak belirlenmiștir. Sıcaklığın horizonlardaki değișimi, maksimum ve ortalama sıcaklıklarda daha fazla olmaktadır.

Entisol topraklarının bazı termal özellikleri Çizelge $4^{\prime}$ 'de verilmiștir. Entisol topraklarda en düșük $\left(16,5^{\circ} \mathrm{C}\right)$ ortalama günlük sıcaklık Mollic Ustifluvent olarak sınıflandırılan profil 3'e ait olan C2 $(47+\mathrm{cm})$ horizonunda belirlenirken, en yüksek ortalama günlük sıcaklık ise profil 2 'in yüzeyinde tespit edilmiștir. Maksimum sıcaklıkta en düșük $\left(18,6^{\circ} \mathrm{C}\right)$ değer Typic fluvent toprağın A2 (18-37 cm) horizonunda, en yüksek değer $\left(37,0^{\circ} \mathrm{C}\right)$ değer ise Mollic Ustifluvent (profil 2) yüzeyinde belirlenmiștir. Minimum sıcaklık değerlerinde en düșük $\left(12,5^{\circ} \mathrm{C}\right)$ sıcaklık değeri Typic Ustifluvent'in A2 (18-37 cm) horizonunda, en yüksek değer $\left(24,5^{\circ} \mathrm{C}\right)$ ise Mollic Ustifluvent'in yüzeyinde saptanmıștır. Entisol topraklarda da ortalama günlük, maksimum ve minimum sıcaklık değerlerindeki değișim yukarı horizonlarda fazla, așağı horizonlarda ise çok düșük olmaktadır.

Toprak katmanlarındaki sıcaklık dalgalarının amplitütü, teorik olarak toprak derinliği boyunca eksponsiyonal olarak azalmaktadır. Eğer derinlik aritmetik olarak artarsa, amplitüt geometrik olarak azalmaktadır. Toprak özellikleriyle beraber, toprak katmanlarının ortalama ve maksimum sıcaklığı amplitütü önemli düzeyde etkilemektedir. Inceptisol toprakların Vertic Haplustept toprakların amplitüt değerleri yüksek olup, 1,2-9,2 ${ }^{\circ} \mathrm{C}$; Typic Haplustept topraklarda ise düșük olup $0,6-5,8{ }^{\circ} \mathrm{C}$ arasında değișmektedir. Entisol topraklarda ise amplitüt değerleri 1,5-7, $8^{\circ} \mathrm{C}$ arasında saptanmıștır (Çizelge 3 ve 4). Toprakların alt horizonlarında ortalama sıcaklığın ve zamana göre sıcaklık değișiminin düșük olması, amplitütün azalmasına neden olan önemli faktörlerdir.

Inceptisol toprakların ısısal yayınım katsayıs yüksek olup, Vertic Haplustept olarak sınıflandırılan

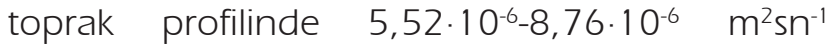
arasında, Typic Haplustept olarak sınıflandırılan toprak profilinde ise $6,17 \cdot 10^{-6}-9,36 \cdot 10^{-6} \mathrm{~m}^{2} \mathrm{sn}^{-1}$ aralığında değișmektedir. Vertic Haplustept sınıfındaki toprakların Bw1 $(23-58 \mathrm{~cm})$ horizonunda tarla kapasitesinin fazla (\% 37,7) olması, Isısal yayınımın da yüksek olmasına etki yapmaktadır. Bw2 (58-90 cm) horizonunda tarla kapasitesinin az, hacim ağılığının ise fazla olmasından dolayı, Ap horizonu ile karșılaștırıldığında ısısal yayınım nispeten yüksek bulunmuștur. Üst horizonlarda kil

Çizelge 3. Inceptisol toprakların sıcaklık $\left({ }^{\circ} \mathrm{C}\right)$, amplitüt $\left({ }^{\circ} \mathrm{C}\right)$ ve ısısal yayınım $\left(\mathrm{m}^{2} \mathrm{sn}^{-1}\right)$ değerleri

Table 3. Temperature $\left({ }^{\circ} \mathrm{C}\right)$, amplitude $\left({ }^{\circ} \mathrm{C}\right)$ and thermal diffusion $\left(\mathrm{m}^{2} \mathrm{sn}^{-1}\right)$ values of Inceptisol

\begin{tabular}{|c|c|c|c|c|c|c|}
\hline \multirow[t]{2}{*}{ Horizon } & \multirow[t]{2}{*}{ Derinlik cm } & \multicolumn{3}{|c|}{ Sicaklık $\left({ }^{\circ} \mathrm{C}\right)$} & \multirow[b]{2}{*}{$\mathrm{Ai} / \mathrm{Ai}+1$} & \multirow[b]{2}{*}{ a } \\
\hline & & Minimum & Maksimum & Ortalama & & \\
\hline \multicolumn{7}{|c|}{ Vertic Haplustept } \\
\hline- & 0 & 20,5 & 35,9 & 26,7 & 9,2 & \\
\hline Ap & $0-23$ & 12,3 & 20,4 & 15,3 & $9,2 / 5,1$ & $5,52 \cdot 10^{-6}$ \\
\hline Bw1 & $23-58$ & 12,0 & 19,7 & 17,2 & $5,1 / 2,5$ & $8,76 \cdot 10^{-6}$ \\
\hline Bw2 & $58-90$ & 11,4 & 16,5 & 15,3 & $2,5 / 1,2$ & $6,91 \cdot 10^{-6}$ \\
\hline $\mathrm{Cl}$ & $90+$ & & & 15,1 & & \\
\hline \multicolumn{7}{|c|}{ Typic Haplustept } \\
\hline- & 0 & 18,4 & 29,7 & 23,9 & 5,8 & \\
\hline Ap & $0-30$ & 14,1 & 20,0 & 17,2 & $5,8 / 2,8$ & $6,17 \cdot 10^{-6}$ \\
\hline Bw1 & $30-64$ & 12,8 & 17,0 & 15,6 & $2,8 / 1,4$ & $8,74 \cdot 10^{-6}$ \\
\hline Bw2 & 64-107 & 10,7 & 14,4 & 13,8 & $1,4 / 0,6$ & $9,36 \cdot 10^{-6}$ \\
\hline C & $107+$ & & & 13,4 & & \\
\hline
\end{tabular}


Çizelge 4. Entisol toprakların sıcaklık $\left({ }^{\circ} \mathrm{C}\right)$, amplitüt $\left({ }^{\circ} \mathrm{C}\right)$ ve ısısal yayınım $\left(\mathrm{m}^{2} \mathrm{sn}^{-1}\right)$ değerleri

Table 4. Temperature $\left({ }^{\circ} \mathrm{C}\right)$, amplitude $\left({ }^{\circ} \mathrm{C}\right)$ and thermal diffusion $\left(\mathrm{m}^{2} \mathrm{sn}^{-1}\right)$ values of Entisol

\begin{tabular}{|c|c|c|c|c|c|c|}
\hline \multirow[t]{2}{*}{ Horizon } & \multirow[t]{2}{*}{ Derinlik, cm } & \multicolumn{5}{|l|}{ Sicaklık $\left({ }^{\circ} \mathrm{C}\right)$} \\
\hline & & Minimum & Maksimum & Ortalama & $\mathrm{A}_{\mathrm{i}} / \mathrm{Ai}_{\mathrm{Ai}+1}$ & a \\
\hline \multicolumn{7}{|c|}{ Typic Ustifluvent } \\
\hline & 0 & 19,5 & 32,6 & 24,8 & 7,8 & \\
\hline Ap & $0-18$ & 13,0 & 20,4 & 17,0 & $7,8 / 3,4$ & $1,71 \cdot 10^{-6}$ \\
\hline$A 2$ & $18-37$ & 12,5 & 18,6 & 17,1 & $3,4 / 1,5$ & $1,96 \cdot 10^{-6}$ \\
\hline C & $37+$ & & & 16,8 & & \\
\hline \multicolumn{7}{|c|}{ Mollic Ustifluvent-1 } \\
\hline & 0 & 24,5 & 37,0 & 28,8 & 8,2 & \\
\hline Ap & $0-21$ & 13,7 & 20,6 & 16,1 & $8,2 / 4,5$ & $4,45 \cdot 10^{-6}$ \\
\hline$A 2$ & $21-55$ & 13,9 & 18,8 & 16,6 & $4,5 / 2,2$ & $8,20 \cdot 10^{-6}$ \\
\hline C & $55+$ & & & & & \\
\hline \multicolumn{7}{|c|}{ Mollic Ustifluvent-2 } \\
\hline & 0 & 20,1 & 33,4 & 26,7 & 6,7 & \\
\hline$A$ & $0-15$ & 14,8 & 21,2 & 18,0 & $6,7 / 3,2$ & $1,50 \cdot 10^{-6}$ \\
\hline $\mathrm{Cl}$ & $15-47$ & 13,5 & 18,9 & 17,4 & $3,2 / 1,5$ & $6,48 \cdot 10^{-6}$ \\
\hline$C 2$ & $47+$ & & & 16,5 & & \\
\hline
\end{tabular}

miktarının fazla olması, ısısal yayınımın artıșının nedenlerinden biri olmaktadır. Organik maddenin fazla bulunduğu Ap $(0-23 \mathrm{~cm})$ horizonunda ısısal yayınım katsayısı düșük $\left(5,52 \cdot 10^{-6} \mathrm{~m}^{2} \quad \mathrm{sn}^{-1}\right)$ bulunmuștur. EC değerlerinin düșük aralıkta değișiminin, ısısal yayınımın değișimine etki yapmadığı söz konusu olabilir. Isısal yayınım toprağın pulluk tabakası (Ap horizonu) dıșındaki diğer horizonlarda, nem içeriği tarla kapasitesindeyken daha yüksek değerler almakta, fakat doygunluk noktasında ise daha düșük değerlere ulașmaktadır (Kurtener, Chudnovskii, 1979; Voronin, 1986; Ekberli vd., 2005 ). Typic Haplustept topraklarda tarla kapasitesi $(\% 38,3)$ ve kil içeriği $(\% 71,8)$ yüksek olması nedniyle, ısısal yayınım da yüksek $\left(9,36 \cdot 10^{-6} \mathrm{~m}^{2} \mathrm{sn}^{-1}\right)$ olarak belirlenmiștir. Yine bu topraklardaki Ap $(0-30 \mathrm{~cm})$ horizonunda organik madde içeriğinin yüksek olmasına karșın, ısısal yayınım ise diğer katmanlarla karșılaștırıldığında düșük $\left(6,17 \cdot 10^{-6} \mathrm{~m}^{2} \mathrm{sn}^{-1}\right)$ olmaktadır. Yüzey altı horizonlarda derinlik artıșıyla beraber amplitütün azalması, kil miktarının artması, hacim ağırlığının düșük değișimi, organik maddenin ise azalması, ısısal yayınımın artmasına etki yapan faktörlerdendir.

Entisol toprakların Typic Ustifluvent'in Ap 10-18 $\mathrm{cm})$ ve A2 (18-37 cm) horizonlarında tarla kapasitesi ve kil miktarının düșük, organik madde miktarının fazla olması nedeniyle ısısal yayınım düșük $\left(1,70 \cdot 10^{-6}\right.$ $\mathrm{m}^{2} \mathrm{sn}^{-1}$ ve 1,96.10-6 $\mathrm{m}^{2} \mathrm{sn}^{-1}$ ) olarak belirlenmiștir. Ayrıca hacim ağırlığının artıșı da ısısal yayınımın artıșına etki yapmaktadır. Mollic Ustifluvent olarak sınıflandırılan topraklarda ise alt horizonlara doğru tarla kapasitesindeki önemli artıș, ısısal yayınımın da artıșına neden olabilmektedir. Dolayısıyla, Mollic Ustifluvent olarak sınıflandırılan 2 nolu profile ait toprakların A2 (21-55) horizonunda ısısal yayınım, Ap $(0-21 \mathrm{~cm})$ horizonu ile karșılaștırıldığında daha yüksek olduğu $\left(8,20 \cdot 10^{-6} \mathrm{~m}^{2} \mathrm{sn}^{-1}\right)$ bulunmuștur. Profil 3'ün (Mollic Ustifluvent) A $(0-15 \mathrm{~cm})$ horizonunda organik madde yüksek, ısısal yayınım katsayısı ise düșük $\left(1,50 \cdot 10^{-6} \mathrm{~m}^{2} \mathrm{sn}^{-1}\right)$ olarak belirlenmiștir. Buna karșılık, Cl (15-47 cm) horizonunda ise, organik madde düșük, ısısal yayınım ise yüksek $\left(6,48 \cdot 10^{-6} \mathrm{~m}^{2} \mathrm{sn}^{-1}\right)$ olarak saptanmıștır (Çizelge 4).

Genel olarak, iklimsel faktörlerle beraber ısısal yayınıma önemli düzeyde etki yapan toprak özelliklerindeki düzensiz değișim, toprak özelliklerinin bir birine olan karșılıklı etkisi vb. ısısal yayınımın da farklı değerlere sahip olmasına sebep olmaktadır (Arkhangel'skaya vd., 2005; Tikhonravova, 2007; Arkhangel'skaya ve Umarova, 2008). Araștırma topraklarının horizonları çoğunlukla killi ve killi tın bünyeye sahiptir. EC değerleri ise 0,01-0.13 dS $\mathrm{m}^{-1}$ arasında değișmektedir. Killi ve killi tın bünyeye sahip topraklardaki ısı yayınımı, toprağın katı fazının içerdiği toprak zerrecikleri ve tuz bileșenlerinin temas aralıklarından gecen ısı iletkenliğinin; toprak havası ortamında olușan ısısal ıșınım ve konveksiyon süreçlerinin yardımıyla gerçekleșmektedir. Tuz miktarının artıșı temas aralıklarının fazla olmasına, dolayısıyla ısı iletkenliğinin artıșına neden olmaktadır. ısısal yayınım ise, ısı iletkenliği ile doğrusal, ısı kapasitesiyle ters orantılı olduğundan, fazla tuz miktarında daha fazladır. Araștırma profillerinin 
horizonlarında tuz miktarı az, değișimi ise dar aralıkta gerçekleștiği için, tuz miktarına bağlı olarak ısısal yayınımda düzenli artıș izlenmemektedir.

\section{Isısal Yayınım Katsayısıyla Bazı Toprak Özellikleri Arasındaki İlișkiler}

Isısal yayınımın toprağın stabil ve stabil olmayan toprak özelliklerine (OM, özgül ağırlık, nem, sıcaklık, kil, silt, kum, tarla kapasitesi vb.) bağlı olarak belirlenmesinde, farklı matematiksel modeller kullanılmaktadır (Tikhonravova ve Khitrov, 2003, Tikhonravova ve Frid, 2008; Arkhangel'skaya, 2009). Tikhonravova (1991) tarafindan yapılan bir araștırmada, toprağın genetik horizonlarındaki hacimsel nem içeriğiyle ısısal yayınım arasında modeller olușturulmuștur.

Toprağın katı, sıvı ve gaz ortamlarını olușturan bileșenleri farklı termofiziksel özelliklere sahip olduğundan, topraktaki ısı yayınımı bu ortamların uygun olarak olușturduğu ısı iletkenliği, ısısal ıșınım, konveksiyon süreçlerinden olușmaktadır. Bu nedenle, heterojen yapıya sahip olan toprağın ısısal yayınımına çok sayıda toprak bileșenleri etki yapmakta ve farklı toprak özelliklerine bağlı olarak farklı regresyon modellerinin yapılması mümkün olmaktadır. Tikhonravova ve Khitrov (2003)'a göre, toprak özelliklerine bağı olarak ısısal yayınımın kesin bir modelinin yapılması imkansız olmakta, yapılan regresyon modellerinin ısısal yayınıma önemli düzeyde etki yapan minimum sayıda parametrelerden olușumu ise, modellerin bölgesel düzeyde uygulanmasını kolaylaștırmaktadır.

İstatistik analiz sonucunda belirlenmiștir ki; Inceptisol ve Entisol olarak sınıflandırılan toprakların ısısal yayınım katsayısı ile tarla kapasitesi arasındaki ilișki $p<0.01$ intimal düzeyinde önemlidir ( $p=0,014$; $R=0,68$ ). Isısal yayınım katsayısı ve tarla kapasitesi arasındaki regresyon ilișki așağıdaki gibi belirlenmiștir (Eșitlik 2).

a. $10^{6}=0.014 W^{2}-052 W+8.79 \quad\left(R^{2}=0.51\right)$

Eșitlik 3' de verilen denklemden görüldüğü gibi, tarla kapasitesinin değișim aralığında ısısal yayınım katsayısı pozitif değerler almaktadır. Tarla kapasitesinin \% 6,9-38,7 aralığında değișimi durumunda, eșitlik $2^{\prime}$ de verilen denkleme göre $\left(\frac{d W}{d a}=0\right.$ koșulundan) $W=\% 18,57$ değerinde, Isısal yayınım teorik olarak $3,96 \cdot 10^{-6} \mathrm{~m}^{2} \mathrm{sn}^{-1}$ minimum değerini almaktadır. Maksimum değer ise; a (\% 387) $=9,63 \cdot 10^{-6} \mathrm{~m}^{2} \mathrm{sn}^{-1}$ olmaktadır. Teorik ve deneysel değerler arasındaki farklıııların nedeni, ısısal yayınım katsayısının özgür özelliği olan düzensiz değișim, diğer toprak özelliklerinin ve iklim faktörünün ısısal yayınıma olan etkisi olabileceği düșünülmektedir.

Isısal yayınım katsayısı ile organik madde, kil ve kum arasındaki ilișki ise sırasıyla $p<0,05(p=0,031$; $R=-0,62), \quad p<0,01 \quad(p=0,005 ; \quad R=0,75), \quad p<0,01$ $(p=0,008 ; R=-0,72)$, intimal düzeyinde önemli olarak saptanmıștır. Doğrusal regresyon ilișkisi ise eșitlik 3' de ifade edilmiștir.

a. $10^{6}=0.327 \mathrm{~W}-1.540 \mathrm{M}+0.019 \mathrm{Kil}+0.073 \mathrm{Kum}-1.68\left(R^{2}=0.79\right)$

Doğrusal olmayan regresyon ilișkileri ise, așağıda verilen eșitlik 4, 5 ve $6^{\prime}$ da verilen biçimde elde edilmiștir.

a. $10^{6}=0.432 \mathrm{~W}-0.007 \mathrm{Kil}+0.095 \mathrm{Kum}-0.2690 \mathrm{M}^{2}-6.0\left(R^{2}=0.81\right)(4)$

a. $10^{6}=0.004 \mathrm{~W}^{2}-0.2080 \mathrm{M}^{2}+4.42\left(\mathrm{R}^{2}=0.78\right)$

a. $10^{6}=0.0009 \mathrm{Kil}^{2}-0.1890 \mathrm{M}^{2}+5.85\left(\mathrm{R}^{2}=0.74\right)$

(4)-(6) regresyon ilișkilerinden de görüldüğü gibi, tarla kapasitesinin artıșı toprağın ısı iletkenliği artıșına, organik maddenin artıșı ise azalmasına neden olmaktadır. Kil ve kumun etkisi ise, toprakların kil ve kum oranına bağlı olmaktadır.

\section{SONUÇLAR}

Araștırma ile Inceptisol ve Entisol ordoları altında sınıflandırılan 4 alt grubun termal özellikleri ve bazı toprak özellikleri ve bunların arasındaki ilișkiler incelenmiștir. Araștırma sonuçları, üzerinde çalıșılan alt grupların yer aldığı Inceptisol ve Entisol ordoları bașlığı altında karșılaștırmalı olarak yorumlanmıı̦tır. Araștırma sonuçlarına göre, Inceptisol ve Entisol toprakların üst horizonları arasındaki sıcaklık farkı yüksek olmakta, alt horizonlara doğru ise bu fark azalmaktadır. Dolayısıyla, așağı horizonlarda sıcaklık değișiminin sabitleșme süreçleri bașlamaktadır. Yukarı horizonlarda yüksek olan amplitüt değerleri, așağı katmanlara doğru azalmaktadır. Horizonlar arasındaki farklı mesafelerde, diğer faktörlerle beraber amplitüt değișimine önemli düzeyde etki yapmaktadır. Isısal yayınım katsayısı așağı horizonlara doğru artmaktadır. Typic Ustifluvent olarak sınıflandırılan toprakta ısısal yayınım katsayısı en düșük, Typic Haplustept olarak sınıflandırılan toprakta ise en yüksek olarak gerçekleșmiștir. Isısal yayınım katsayısı yüksek olan așağı horizonların ısınması ve soğuması daha çabuk gerçekleșmektedir. Organik maddenin fazla olması ısısal yayınımın azalmasına, tarla kapasitesi ve kil miktarının fazla olması ise artmasına neden 
Olmaktadır. Değișim aralığı çok düșük olan parametrelerin (EC, HA) ise, Isısal yayınıma etkisinin az olması düșünülmektedir. Toprakların ısısal yayınım katsayısının detaylı olarak araștıııması, optimum sıcaklık ortamının olușturulması için gerekli yöntemlerin belirlenmesinde önemli olduğundan, farklı iklim ve toprak koșullarında daha fazla araștırmanın yapılmasını gerektirmektedir

\section{KAYNAKLAR}

Arias-Penas D, Castro-Garcia M P, Rey-Ronco M A, AlonsoSanchez T (2015). Determining the thermal diffusivity of the ground based on subsoiltemperatures. Preliminary results of an experimental geothermalborehole study Q-THERMIE-UNIOVI. Geothermics, 54: 35-42.

Arkhangel'skaya T A 120099. Parameterization and mathematical modeling of the dependence of soil thermal diffusivity on the water content. Eurasian Soil Science, 42(2): 162-172.

Arkhangel'skaya, TA (2004). Thermal diffusivity of gray forest soils in the Vladimir Opolie region. Pocvovedeniye, 3: 332-342.

Arkhangel'skaya, T A, Guber A K, Mazirov M A, Prokhorov M V (2005). The temperature rejime of soils in Vladimir Opol'e Region. Pocvovedeniye, 7: 832-843.

Arkhangel'skaya, T A, Umarova A B (2008). Thermal diffusivity and temperature regime of soils in large lysimeters of the experimental soil station of Moscow State University. Pocvovedeniye, 3: 311-320.

Blake G R, Hartge K H (1986). Bulk Density and Particle Denstity. In: Methods of Soil Analysis, Part I, Phsical and mineralogical Methods. p: 363-381. ASA and SSSA Agronomy Monograph no: 9(2 ${ }^{\text {nd }}$ ed), Madison

Bouyoucous G J (1951). A Recalibration of hydrometer for making mechanical analysis of soils. Agronomy Journal. 43: 9

Correia A, Vieira G, Ramos M (2012). Thermal conductivity and thermal diffusivity of cores from a 26 meter deep borehole drilled in Livingston Island, Maritime Antarctic. Geomorphology, 155(156): 7-11.

Dinç U, Kapur S, Özbek H, Șenol S (1987). Toprak Genesisi ve Sınıflandırması. Adana: Çukurova Üniversitesi Basımevi. C..Ü. Yayınları Ders Kitabı, No 7.1.3.

Ekberli I, Gülser C (2014). Estimatıon of soil temperature by heat conductivity equation. Vestnik Bashkir State Agrarian University (Вестник Башкирского Госуд арственного Аграрного Университета), 2 (30): 12-15.

Ekberli i, Gülser C, Özdemir N (2015). Toprakta Is| iletkenliğine etki yapan ısısal parametrelerin teorik incelemesi. Anadolu Tarım Bilimleri Dergisi, 30(3): 300-306.

Ekberli I, Gülser C, Özdemir N (2005). Toprakların termofiziksel özellikleri ve ısısal yayınım katsayısının değerlendirilmesi. O.M.Ü. Zir. Fak. Dergisi, 20(2): 85-91.

Ekberli I, Sarılar Y (2015). Toprak sıcaklığı ve ısısal yayınımın belirlenmesi. Anadolu Tarım Bilimleri Dergisi, 30(1): 74-85.

Gao Z, Bian L, Hu Y, Wan L, Fan J (2007). Determination of soil temperature in an arid region. Journal of Arid Environments, 71: 57-168.
Ghuman B S, Lal R (1985). Thermal conductivity, thermal diffusivity and thermal capacity of some Nigerian soils. Soil Sci., 139: 74-80

Gülser C, Ekberli I (2004). A comparison of estimated and measured diurnal soil temperature through a clay soil depth. J. of Applied Sci., 4(3): 418-423.

Gülser C, Ekberli I (2002). Toprak sıcaklığının profil boyunca değișimi. O.M.Ü. Zir. Fak. Dergisi, 17(3): 43-47.

Hinkel K M (1997). Estimating seasonal values of thermal diffusivity in thawed and frozen soils using temperature time series. Cold Regions Science and Technology, 26:1-15.

Jackson M L (1958). Soil Chemical Analysis. Prentice Hall Inc., Englewood Cliffs, N.J.

Jenny H (1980). Factors of Soil Formation. McGraw-Hill, Newyork, p 281

Kurtener D A, Chudnovskii A F (1979). Toprakların ısı düzenlemesinde agrometorolojik temeller Leningrad, Gidrometeoizdat, 231s. (Rusça).

Onder O, Ozgener L, Tester JW (2013). A practical approach to predict soil temperature variations for geothermal (ground) heat exchangers applications. International Journal of Heat and Mass Transfer, 62: 473-480.

Passerat de Silans A M, Monteny B A, Lhomme J P (1996). Apparent soil thermal diffusivity, a case study: HAPEX-Sahel experiment. Agricultural and Forest Meteorology, 81: 201-216.

Richards L A (1954). Diagnosis and Improvement of Saline and Alkaline Soils. U.S. Dept. Agr. Handbook, 60, 109. Riverside.

Soil Survey Staff (1992). Procedures for collecting soil samples and methods of analysis for soil survey. Soil Surv. Invest. Rep. I. U.S. Gov. Print. Office, Washington D.C. USA.

Soil Survey Staff (1993). Soil Survey Manual, USDA. Handbook No: 18 Washington D.C.

Soil Survey Staff (1999). Soil Taxonomy. A Basic of Soil Classification for Making and Interpreting Soil Survey. U.S.D.A Handbook No: 436, Washington D.C.

Sterling A T, Jackson R D (1986). Temperature. In: Klute, A. (Ed.), Methods of Soil Analysis Part 1. Physical and Mineralogical Methods. Agronomy Monograph No: 9, ASA, SSSA, Madison WI.

Tanju Ö (1996). Toprak Genesisi ve Sınıflandırma. Ankara Üniversitesi Ziraat Fakültesi. Yayın No: 1472, Ders Kitabı No: 437, Ankara.

Tikhonravova PI (1991). Assessment of the thermophysical properties of soils in the transvolga Solonetzic Complex. Pochvovedenie, 5: 50-61.

Tikhonravova PI (2007). Effect of the water content on the thermal diffusivity og clay loams with different degrees of salinization in the Transvolga region. Pocvovedeniye, 1: 55-59.

Tikhonravova P I, Frid A S (2008). Mathematical Models of thermal diffusivity in solonetz soils in the Trans-Volga Region of Volgograd oblast. Eurasian Soil Science, 41 (2): 190-201.

Tikhonravova P I, Khitrov N B (2003). Estimation of thermal conductivity in Vertisols of the Central Ciscaucasus region. Pocvovedeniye, 3: 342-351. 
Trombotto D, Borzotta E (2009). Indicators of present global warming through changes in active layer-thickness, estimation of thermal diffusivity and geomorphological observations in the Morenas Coloradas rockglacier, Central Andes of Mendoza, Argentina. Cold Regions Science and Technology, 55: 321-330.

Usowicz B, Kossowski J, Baranowski P (1996). Spatial variability of soil thermal properties in cultivated fields. Soil \& Tillage Research, 39: 85-100.
Verhoef A, van den Hurk B J J M, Jacobs A F G, Heusinkveld B G (1996). Thermal soil properties for vineyard (EFEDA-I) and savanna (HAPEXSahel) sites. Agricultural and Forest Meteorology, 78: 1-18.

Voronin A D (1986). Basic Physics of Soils (Mosk. Gos. Univ., Moscow), 246 p. (in Russian).

Wang Z H, Bou-Zeid E (2012). A novel approach for the estimation of soil ground heat flux. Agricultural and Forest Meteorology, 154- 155: 214-221. 